December 2006

\title{
Genocide and Atrocity Crimes
}

David Scheffer

Follow this and additional works at: https://digitalcommons.usf.edu/gsp

\section{Recommended Citation}

Scheffer, David (2006) "Genocide and Atrocity Crimes," Genocide Studies and Prevention: An International Journal: Vol. 1: Iss. 3: Article 3.

Available at: https://digitalcommons.usf.edu/gsp/vol1/iss3/3

This Articles is brought to you for free and open access by the Open Access Journals at Digital Commons @ University of South Florida. It has been accepted for inclusion in Genocide Studies and Prevention: An International Journal by an authorized editor of Digital Commons @ University of South Florida. For more information, please contact digitalcommons@usf.edu. 


\title{
Genocide and Atrocity Crimes
}

\section{David Scheffer \\ Center for International Human Rights, Northwestern University School of Law}

\begin{abstract}
The term "genocide" has been commonly used, particularly in political dialogue, to describe atrocities of great diversity, magnitude, and character. Yet the prospect of the term's arising in policy making too often imposes an intimidating brake on effective responses. The political use of the term should be separated from its legal definition as a crime of individual responsibility. Governments and international organizations should be liberated to apply the term "genocide" more readily within a political context so as to publicly describe precursors of genocide and react rapidly either to prevent or to stop mass killings or other seeming acts of genocide. They should not be constrained from acting by the necessity of a prior legal finding that the crime of genocide in fact has occurred or is occurring and, once that legal finding has been made, that governments are somehow obligated to use military force in response. There also is a critical need for a new term-“atrocity crimes"-and a new field of international law-atrocity law-to achieve a similar objective, namely, to enable public and academic discourse to describe genocide, crimes against humanity (including ethnic cleansing), and war crimes with a single term that is easily understood by the public and accurately reflects the magnitude and character of the crimes adjudicated before international and hybrid criminal tribunals and of the law being applied by such tribunals, governments, and international organizations. The purpose would be to simplify and yet render more accurate both public dialogue and legal terminology describing genocide and other atrocity crimes.
\end{abstract}

In this article I advance two proposals. First, there is a critical need to liberate governments and international organizations from the genocide factor, by which I mean to enable them to readily identify precursors of genocide without being constrained by the legal requirements that must be met to properly identify the crime of genocide. Second, I believe it is essential that we transform the terminology used in scholarship, public documents, and public dialogue regarding the crime of genocide, crimes against humanity (including ethnic cleansing), and war crimes into a more adaptable and accurate vehicle for the collective description of these crimes, and that the relevant term should be "atrocity crimes" while the associated discipline should be described as "atrocity law."

\section{Liberating Governments and International Organizations from the Genocide Factor}

This topic presents a very difficult challenge. On the one hand, I will argue that governments and international organizations, particularly the United Nations, need to be liberated to apply the term "genocide" more readily in describing and reacting to mass killings that appear to have genocidal intent-whether occurring over a short or a long period-rather than being constrained by the necessity of a legal finding that, 
in fact, the crime of genocide has occurred or is occurring. In other words, I want to draw a distinction between the political application of the term "genocide" and the legal application of that term. Beyond that, the historical application of the term has far-reaching but different ramifications from its political and legal applications.

On the other hand, I will argue in my second proposal that we need to go even further and describe as "atrocity crimes" a grouping of crimes that includes genocide but is not confined to that particular crime. In short, we need to simplify and, indeed, render more accurate both public dialogue and legal terminology about such crimes. At present, there is far too much confusion and garbled terminology about what is in fact occurring in an atrocity zone.

These two arguments might appear, at first glance, to be at cross purposes. How can we liberate the use of the term "genocide" while at the same time sharpening its precise application within the realm of international politics and law? To answer that question, one might begin by focusing on the political application of the term that merits a liberating influence.

Raphael Lemkin recognized the need for a new term to describe the type of human destruction that no other legal term had adequately covered up through World War II, and his introduction of the term "genocide" filled a gap in terminology that has had a profound impact on law, culture, history, and politics since the late $1940 \mathrm{~s} .{ }^{1}$ But the term "genocide" has proved insufficient and even, at times, counterproductive. The range of criminal conduct that involves assaults on civilian populations and the misuse of military power in armed conflict extends far beyond the relatively narrow confines of the crime of genocide. Yet the term has been commonly used, particularly in political dialogue, to describe atrocities of great diversity, magnitude, and character. Political officials and observers have reached a stage where every mass killing, whether immediate or drawn out over long periods, soon evokes the language of genocide and its all too often intimidating brake on effective responses. As an almost perverse methodology, governments and institutions seem incapable of responding effectively to atrocities because these have not yet been determined to be genocide. If and when such events are painstakingly defined as genocide, the same governments and organizations are paralyzed, prevented from acting by the presumption that any action will trigger that nation's or organization's legal responsibility to commit enough personnel and resources, and stay the course long enough, to defeat the forces of genocide. Effective action in the face of genocide, in contrast to cautious inaction, can also challenge precepts of international law prohibiting the use of military force or other punitive measures without, for example, explicit Security Council enforcement authorization under chapter VII of the UN Charter.

I witnessed this phenomenon in the US government and at the United Nations many times during my public service in the Clinton administration. During the early years of the administration, officials seemed incapable of definitive action unless and until genocide was determined to have occurred, and even then action was problematic because either too much time had elapsed, and the killing had subsided, or the larger responsibility any timely and effective response might trigger was too much to shoulder politically. Probable genocide in Burundi in the fall of 1993 evoked no response at all. Genocide in Rwanda in 1994 generated a pathetic and disastrously delayed response. Genocide in southern Sudan throughout the 1990s led only to diplomatic and humanitarian efforts. Genocide in the Balkans during the early 1990s generated many diplomatic, humanitarian, judicial, and peacekeeping responses, but very little that proved effective until a single genocidal event, the Srebrenica massacre 
in July 1995, finally triggered decisive military actions leading to the Dayton Accords later that year. Probable genocide in the southern marshes of Iraq during the 1990s colored a tough US policy toward Iraq during those years but resulted only in sustaining the no-fly zone over the south and the UN sanctions regime, rather than spurring intervention to reverse the genocidal policies of Saddam Hussein's regime. Possible genocide in the Democratic Republic of the Congo in the late 1990s prompted only diplomatic and ultimately UN peacekeeping initiatives, but the killing there continues to this day, and no one is volunteering to trump the peacekeeping effort with a humanitarian intervention. Even in Kosovo in 1999, when genocide appeared to be a strong possibility, NATO's response was confined to air power rather than invoking the combined might of air and ground power, which might have averted further killing by Serb military and paramilitary forces.

Since February 2003 the United States and the international community have faced a similar challenge with respect to the situation in Darfur, Sudan. Once again, action initially hinged on a finding of genocide, which the US government arrived at by September 2004, albeit some eighteen months after the killing and ethnic cleansing began in Darfur. ${ }^{2}$ (This was about how long it took for the Clinton administration, once in office, to arrive at a similar conclusion regarding Bosnia and Herzegovina.) Yet the term "genocide" has proved quite daunting, perhaps even more so once it was so determined. One wonders whether the Bush administration remains fearful that, if it were to act effectively on the evidence of genocide, it would trigger an unacceptable responsibility to go the full distance to stop genocide in Darfur. Why confront genocide head-on in Darfur if the result would create intolerable pressure on the United States to shoulder the full, or nearly full, responsibility of genocide prevention in that region-perhaps more so during the next crisis-as well as the risk of contravening the UN Charter and customary international law on the use of force?

Governments, as opposed to prosecutors and courts, need to understand and apply the term "genocide" largely in a preventive rather than a criminal context. It has become folly of the most profound character to insist that a government, or the UN Security Council, must first take the time and effort to determine, under international criminal law, that the crime of genocide has been committed before taking military action or, if it can work quickly enough, diplomatic or economic measures to stop what might be, but may turn out not to be, genocide.

The article I obligation under the Convention on the Prevention and Punishment of the Crime of Genocide (UNCG) that contracting parties "undertake to prevent and to punish" the crime of genocide ${ }^{3}$ cannot possibly be met unless governments, and the international or regional organizations through which they sometimes prefer to act, respond on the basis of political, not legal, judgments about what is actually occurring in the field. Those political judgments may be flawed, based on initial intelligence and open-source reporting from the field that may prove erroneous over time; they may be driven more by the urgency of a violent situation than by rigorous legal scrutiny of the intentions and actions of individuals throughout the chain of command. A government may be disproved in its initial assessment that another government, a separatist movement, or a militia group has committed genocide. Perhaps the violence turns out to be crimes against humanity. But unless there is some fairly flexible policy that governments can employ, without attracting charges of character assassination, to allege what appears to be an emerging genocide and then respond vigorously to stop it, the academic discourse and political rhetoric about preventing and stopping genocide will continue to be detached from reality. 
Governments should be liberated to describe quickly and publicly the precursors of genocide that may ultimately establish the crime of genocide but, at a minimum, should alert the world to the need to react in a timely manner to prevent further destruction of innocent human life, whether in times of armed conflict or in times of internal repression. This, of course, is only one facet of genocide prevention, namely, the terminology employed, and what is proposed in this article supplements the many existing proposals on genocide prevention and how to achieve it operationally. Governments, international and regional organizations, and the media should regard the term "precursors of genocide" as significant on a political, not legal, level. The term is useful, pragmatic, and sufficiently diplomatic to be employed without necessarily triggering some of the intimidating consequences of charges of genocide. It reflects a judgment that precursors of events that may constitute the crime of genocide are apparent. The recognition of precursors of genocide may put just enough pressure about possible genocide in the public domain to encourage governments and relevant international and regional organizations to respond faster and more effectively, without the almost paralyzing pressure that builds with the bald use of the term "genocide."

In April 1999, I had the opportunity to articulate a similar term, "indicators of genocide," during the opening days of the Kosovo conflict of that period, when Serb military and paramilitary forces were crossing into Kosovo and unleashing violent ethnic cleansing and murderous assaults on the Kosovar Albanian population. There is some value in examining precisely what the Clinton administration did at that time that led to the use of the term "indicators of genocide." I have reached the conclusion since then that an alternative term, "precursors of genocide," would be a more appropriate one to use in the future. The term "indicators of genocide" has evolved to denote the many political, sociological, economic, military, and diplomatic events that occur long before actual genocide takes place and which point to trends that may erupt into genocide at some point in the future. This is a vital exercise, and one that I engaged in intensively as chair of the US government's Atrocities Prevention Inter-Agency Working Group in 1999 and 2000, working closely with academic experts and the intelligence community on various schematic diagrams of such indicators of genocide. But the exercise has been refined since then to give the term "indicators" a far more rigorous lock on a host of factors, some with long lead time, leading to genocide.

The term "precursors of genocide" refers to those events occurring immediately prior to and during possible genocide that can point to an ultimate legal judgment of genocide but which should be recognized and used in a timely manner to galvanize international action to intervene, be it diplomatically, economically, or militarily. My primary concern is to employ a term that stimulates, rather than retards, effective action by governments and international organizations, particularly the United Nations, to stem the tide of genocide (whether or not, as a matter of law, what unfolds in the field is ultimately concluded to be genocide). But in 1999, as a government official struggling with dynamic events unfolding, I turned to the more familiar term "indicators," without making a rigorous distinction between long-term and short-term phenomena related to genocide, and used it in largely the same context as one now would use the term "precursors."

On 28 March 1999, I convened an inter-agency meeting of intelligence, political, and military analysts and lawyers at the State Department for several hours of discussion about how the events unfolding in Kosovo should be described publicly. 
In our review at the meeting, participants fairly rapidly concluded that Serb military and paramilitary forces were committing crimes against humanity, given the widespread and systematic character of the actions on the ground and the particular violence being unleashed. We turned our attention to whether genocide was being committed against the Kosovar Albanian population of Kosovo. As I later explained in a press briefing on 9 April 1999, many of what I called "indicators of genocide" had become apparent, and we believed it important, as a government, to state that conclusion publicly. I described the indicators of genocide as including the then historical context of the scorched-earth policy of death and destruction that had already been recorded from the spring, summer, and fall of 1998 in Kosovo. I said,

The pattern was established in 1998. Indeed, one might consider what happened in 1998, as a practice run for what was unleashed with remarkable speed and thoroughness in the last few weeks [of March and April 1999]. Milosevic and the Serb leadership are trying to bring to closure what they began in 1998. Now, the events of the last few weeks exceed in magnitude and ferocity all that occurred in 1998. Without question Serb assaults on the civilian population of Kosovo are widespread and systematic. $^{4}$

I reminded the press of the definition of crimes against humanity given in the Statute of the International Criminal Tribunal for the Former Yugoslavia and of our conclusion that many such crimes were being committed in Kosovo. I also pointed to war crimes, including the destruction of civilian property.

I then extended the analysis into events that, when viewed within the context of ongoing crimes against humanity and war crimes, pointed to the crime of genocide as well. These indicators of genocide, occurring within a very short period (namely, the previous three weeks), included ${ }^{5}$

1. The forced expulsion of large segments of the ethnic Albanian population, on a scale not seen in Europe since World War II. I showed a map clearly demonstrating that internal displacement and destruction of towns had taken place almost entirely within the ethnic Albanian regions of Kosovo. The map demonstrated the systematic way in which Kosovar Albanian areas of Kosovo were assaulted "without much appreciable damage or internally displaced populations from those areas that are largely populated by Serbs." As part of the destructive pattern, I noted the "forced removal of Albanians from their homes at gun point; destruction of all official and identifying documents; cramming of Albanians into trains; infliction of unsanitary conditions on the trains, etc." At the time we saw this kind of conduct as reflecting, at a minimum, an article II(c) violation of the UNCG, namely "deliberately inflicting on the group conditions of life calculated to bring about its physical destruction in whole or in part."

2. The detention and summary execution of military-aged men and mass executions. Refugees had provided accounts of summary executions in at least fifty towns and villages throughout Kosovo. I reported that "some accounts refer to large numbers of Kosovars being killed in apparent massacres." The reported killings included targeting of intellectuals and leaders; separating fighting-aged men from the group and killing them; causing serious bodily harm; and mass executions. These events reflected the possibility of violations of article II(a) ("killing members of the group") and article II(d) ("imposing measures intended to prevent births within the group") of the UNCG. 
3. The "burning and destruction of civilian homes and villages." I presented a map of Kosovo showing 220 sites of village destruction and said that, as of 9 April, the number had increased to 250 sites and continued to rise. (By mid-May 1999, the number had risen to well over 600.) I described the character of destruction in the villages, the lack of any battle damage, and the ethnic objective that appeared evident in the pattern of destruction. This destruction pointed to article II(c) of the UNCG ("deliberately inflicting on the group conditions of life calculated to bring about its physical destruction in whole or in part") as well as article II(b) ("causing serious bodily or mental harm to the members of the group"). The US government had received many reports of injuries and killings, many of a sadistic character, occurring during these destructive sweeps of villages and towns, and officials logically inferred from such events that serious mental harm was being inflicted on the fleeing Kosovar Albanians.

I concluded this analysis by saying that "if you take the totality of this information that we have acquired so far, we believe that it creates the basis for stating that there are indicators of genocide unfolding in Kosovo." Toward the end of the press briefing, I was asked by a reporter what difference it made that I believed that what was unfolding on the ground in Kosovo must reflect a planned operation executed pursuant to a policy. I responded,

Let's just say that obviously, if you can demonstrate a well thought out plan that has an intent behind it, then-that's why we point to indicators of genocide. But I want to emphasize that regardless, you can have a very well planned campaign of crimes against humanity, and there is no question that that's what's unfolded in Kosovo. ${ }^{6}$

Following use of the term "indicators of genocide," the pressure from the media to describe the Kosovo events as genocide dissipated. In other words, I firmly believe that as long as there is a credible acknowledgment that genocide may be unfolding, the media and the public will not insist on a definitive finding of genocide quickly or as a predicate to action by a government or organization. They do want to know that the genocide factor is acknowledged, recognized in some fashion, and kept in the forefront of policy making and decision making during an atrocity. Where a government, like the US government in 1999, can at least confirm that precursors of genocide are apparent, and that the government or organization (as the case may be) is responding to those precursors of genocide, then the pressure to conclude that the crime of genocide has occurred or is occurring becomes far less significant. What becomes important is the action being taken to prevent genocide rather than the search for the crime of genocide. In the case of Kosovo, the debate in April and May 1999 focused on whether to send in ground troops, not on whether the crime of genocide was taking place.

It is that determination of precursors of genocide that permits a political, as opposed to legal, judgment to surface far more rapidly among public officials. As shown by my own remarks during the Kosovo conflict, one can state more definitively the legal judgment of crimes against humanity and war crimes in real time, but specific intent requirements make legal judgments about genocide far more difficult to arrive at quickly. Governments should be liberated to use "precursors of genocide" in their public statements once those indicators begin to emerge from the field and thus trigger the UNCG's obligation, under article I, to act to prevent genocide as quickly and effectively as possible. What logic would that obligation convey if a government had to wait until the crime of genocide is established to prevent it? 
One may liken this to the significance of saying that acts of genocide have occurred, which the United States and the United Nations did regarding the Rwandan genocide of 1994 before the term "genocide" was used. ${ }^{7}$ But I counsel against use of that term, as it is a critical component of any legal determination about the crime of genocide. The legal determination combines an act of genocide with the specific intent to destroy, in whole or in part, a designated group. In the public dialogue, however, I do not believe that any good purpose is served by distinguishing between "acts of genocide" and "genocide"; in other words, in public officials' either trying to manipulate the distinction to avoid the responsibility to act or being held accountable by the media for innocent application of the two terms interchangeably, or absent sophisticated knowledge of the distinction in law. In contrast, precursors of genocide can be associated more readily with evidence of an inferred intent, although a finding of such intent should not be a prerequisite to the use of the term "precursors of genocide."

Preventive action need not, as a matter of law, involve military action. A whole range of tools is available, including diplomatic initiatives; economic sanctions; judicial initiatives with international, hybrid, or national criminal tribunals; and, under relevant circumstances, military action. Some might argue that the requirements of the UN Charter and customary international law must be strictly complied with prior to the use of force in response to genocide. No state would have ratified the UNCG if it imposed an unyielding obligation for that state to use military force on foreign territory every time genocide is claimed. There is the option, under article VIII of the UNCG, for any contracting party to "call upon the competent organs of the United Nations to take such action under the Charter of the United Nations as they consider appropriate for the prevention and suppression of acts of genocide or any of the other acts enumerated in article III." But there is no obligation to do so, and, as we know, there is no certainty whatsoever that the "competent organ" of the United Nations, which typically would be the Security Council, would indeed take any such action.

The use of the term "precursors of genocide" does not guarantee that the political and legal obstacles to a humanitarian intervention in any particular situation will be lowered. But greater reliance by governments and organizations on using this term might weaken the all-too-familiar resistance to effective action from governments seeking and relying on the long lead time required for a finding of genocide before there is real pressure to respond to genocidal events. There must be a more serious effort to break the back of the myth that governments and organizations are paralyzed, prevented from acting, until a finding of genocide has been made, however important that finding will ultimately be for any criminal prosecution and for critical historical accounts of what actually happened. The pathway to action against genocide must be simplified; governments must not be frozen into inaction while awaiting legal determinations about atrocities that appear genocidal in character but which would require intensive legal scrutiny and historical research before the crime of genocide could be established.

In the case of Darfur, the precursors of genocide had begun to appear by early 2003. ${ }^{8}$ Even if it had taken, say, six months for a recognition that precursors of genocide were apparent to spur governments into action, there would have been a much better chance of reversing genocidal developments in Darfur by the end of 2003, rather than placing the people of Darfur in the untenable position in which they find themselves today. Instead, governments, the United Nations, and the African Union appeared dependent on the word "genocide" as the predicate to responsible reaction to the events unfolding in Darfur. On the one hand, it is to the credit of the US 
government that it undertook a genocide analysis of Darfur in 2004 and, in September of that year, determined that genocide was indeed occurring in Darfur. But, on the other hand, that exercise retarded effective action on the ground to prevent further genocide until the finding was released, and, not surprisingly, the finding of genocide has raised the legal stakes so high that the response of the United States remains limited.

If the United States had simply concluded in 2003, or even early 2004, that precursors of genocide were present in Darfur, and then effectively acted, unilaterally or multilaterally, to ensure that the crime of genocide would not commence or continue thereafter, many lives would doubtless have been saved. The genocide analysis of the summer of 2004 could still have been productively undertaken, but the preventive action would have long preceded it, rather than trailing in the aftermath. Similarly, the International Commission of Inquiry (COI) on Darfur might have benefited from employing the term "precursors of genocide" rather than concluding, as it did, that the crime of genocide and the necessary individual criminal responsibility had not been established and, thus, genocide could not be determined. ${ }^{9}$ In fact, the commission found no policy of genocide in Sudan. ${ }^{10}$ Such a finding is puzzling because the evidence appears to show that there are precursors of a policy of genocide that must be recognized at the political level first, and thus trigger an effective response, before there is enough information and evidence for a legal finding of the crime of genocide. Unfortunately, the commission approached its task as a strictly legal one, as if its only function was to reach determinations that would be admissible in a court of law. It could have fulfilled an important political role by looking for information that would point to precursors of genocide, describe it simply as such, and avoid, at least temporarily, any firm conclusions that the crime of genocide had in fact occurred. Instead, it left the door wide open for the Sudanese government to capitalize on the commission's finding that there is no policy of genocide. ${ }^{11}$

The COI's finding that there have been war crimes and crimes against humanity in Darfur, however, is commendable, as is the commission's emphasis that these crimes must be taken as seriously as genocide and justice be rendered with as much determination as if genocide had been determined. ${ }^{12}$ That focus on war crimes and crimes against humanity, in particular, should have had more impact on governments, the Security Council, and the media and public. As it stands, the commission's January 2005 finding that there is no policy of genocide in Sudan may one day be shown to have been so debilitating to preventive and responsive actions as to have limited the flow of resources to the African Union monitoring force, retarded efforts to introduce combat troops on Darfurian territory, shifted primary focus to continued (although greatly disrupted) humanitarian aid efforts, and complicated largely futile diplomacy by the United Nations.

The primary objective in relying on a more liberal understanding of genocide, however, is to establish state responsibility far more readily than is currently possible under the criminal-intent requirements of individual accountability. Such an understanding would give policy makers the freedom to point a finger at a state's responsibility for actions that appear genocidal in real time, without having to prove the direct responsibility of any individual leader or military commander for the crime of genocide-which is what appears to have so constrained the International Commission of Inquiry on Darfur.

Thus, one could point to acts of genocide, as defined by articles II and III of the UNCG, and express the political point that a government appears to be committing 
such acts of genocide, which it must be prevented from continuing to commit, regardless of who, within such a government or military or militia force, can be shown to demonstrate the requisite specific intent required to convict an individual for the crime of genocide. The state and the government must be seen to be responsible for the acts of genocide, and the witnesses of these events must, at the governmental and organizational levels, be empowered to allege that at least precursors of genocide are apparent and that they merit strong political and, in all likelihood, military responses. This divide-between the political reality of genocide and the criminal character of genocide-must be more broadly accepted if there is to remain any chance of preventing genocide from continuing once it has erupted in an atrocity zone.

\section{The Terminological Imperative of "Atrocity Crimes" and "Atrocity Law"}

Having argued that governments and organizations should be permitted to apply the more flexible term "precursors of genocide" to certain unfolding atrocities that point to the crime of genocide, I believe that it is imperative that there be introduced an even more adaptable terminology to describe genocide and other atrocities meriting effective governmental and organizational responses.

During the first pursuit scene in the movie The Fugitive, Dr. Richard Kimble (played by Harrison Ford) yells, "I didn't kill my wife!"; US Deputy Marshal Samuel Gerard (played by Tommy Lee Jones) responds, "I don't care!"13 I am reminded of that exchange every time the genocide factor rears its head on the international scene. Claims abound that there is no genocide, or that the government has not committed genocide, or that there must be a determination as to whether or not genocide has occurred before any further action can be taken.

The collective response to any political leader, any military or militia commander, or any international or regional organization denying the existence of genocide or balking at taking effective action, on the premise that a finding of genocide is first required, should be, "We don't care!" We should not care, because the crimes that make up the subject-matter jurisdiction of the international and hybrid criminal tribunals constituted since 1993 range far beyond the crime of genocide, and rightly so. These tribunals- the International Criminal Tribunals for the Former Yugoslavia and Rwanda, the Special Court for Sierra Leone, the Extraordinary Chambers in the Courts of Cambodia, the permanent International Criminal Court, the special War Crimes Chambers in Bosnia, the Iraqi High Criminal Court, and the special war crimes courts established in Kosovo and East Timor-have jurisdiction over atrocity crimes.

Just as the term "precursors of genocide" should be more easily invoked by governments when confronted with apparent acts of genocide, so too should public officials, military officers, the media, and academics be free to describe genocide, crimes against humanity (including the emerging crime of ethnic cleansing), and serious war crimes as atrocity crimes meriting timely and effective responses in political, military, and judicial terms. Repeatedly, all manner of official documents, public statements, and scholarly works struggle to find the right terminology for the range of crimes associated with atrocities, and one is left with fragmentary and very often inaccurate descriptions of the range of crimes involved. Should one refer to "genocide and crimes against humanity," or perhaps "violations of international humanitarian law," or perhaps "genocide and war crimes," or perhaps "genocide, crimes against humanity, ethnic cleansing, and war crimes," or perhaps just 
"genocide"? A certain sloppiness has infected public dialogue, official documents, and even scholarly works. A unifying term is needed to easily and accurately describe the totality of these crimes. ${ }^{14}$

I plead for a new category of crimes called "atrocity crimes" and for a new field of international law that describes the law covering atrocity crimes, both in the realm of state responsibility and in the domain of individual accountability. That body of law I would describe as "atrocity law," which essentially encompasses the law of the international and hybrid criminal tribunals. Just as the term "genocide" originally captured what Raphael Lemkin recognized as the essence of a particular crime against humanity requiring special identification in public, legal, and historical terms, so too does the term "atrocity crimes" describe a basket of particularly heinous crimes that are suitable for criminal prosecution before international tribunals and national courts and for which states and certain non-state organizations and groups should be held responsible. Atrocity crimes also are collectively executed crimes of such magnitude and destructive character as to be particularly prominent and logically inconsistent with the protection of human rights and the maintenance of international peace and security in an increasingly interdependent and sophisticated global society.

\section{Atrocity Crimes}

The word "atrocity" (or "atrocities") derives from Roman military law. It described illegal acts performed pursuant to military orders, acts that today might also prove illegal unless shielded by a modern application of the "defense of superior orders." Professor Mark Osiel, in his well-documented book Obeying Orders, writes that "This word [atrocities] never became a legal term of art, however, with a settled meaning distinct from ordinary Latin. It no longer occupies any place within the formal language of international military law." 15 For that reason there is a fairly clean slate upon which to use the word "atrocity" as a legal term, particularly in light of what has occurred since the early 1990s and the popular usage of the term "atrocity" by governments, intergovernmental and non-governmental organizations, and the media.

Atrocity crimes fit the following profile of cumulative definitional characteristics, all of which must exist for the term to be used accurately:

1. The crime must be of significant magnitude, meaning that its commission is widespread or systematic or occurs as part of a large-scale commission of such crimes. The crime must involve a relatively large number of victims (e.g., a fairly significant number of deaths or casualties), or impose other very severe injury upon noncombatant populations (e.g., massive destruction of private property), or subject a large number of combatants or prisoners of war to violations of the laws and customs of war.

2. The crime may occur in time of war, or in time of peace, or in time of violent societal upheaval of some organized character, and may be either international or non-international in character.

3. The crime must be identifiable in conventional international criminal law as the crime of genocide, a violation of the laws and customs of war, the crime of aggression (if and when it is defined so as to give rise to clear individual criminal culpability), the crime of international terrorism, a crime against humanity (the precise definition of which has evolved in the development of the criminal tribunals), or the emerging crime of ethnic cleansing. 
4. The crime must have been led, in its execution, by a ruling or otherwise powerful elite in society (including rebel or terrorist leaders) who planned the commission of the crime and were the leading perpetrators of the crime.

5. The law applicable to such crime, while it may impose state responsibility and even remedies against states, is also regarded under customary international law as holding individuals criminally liable for the commission of such crime, thus enabling the prosecution of such individuals before a court duly constituted for such purpose.

A crime that meets all five of these criteria would, in my view, be an atrocity crime. In non-legal terms, these are high-impact crimes of severe gravity that are of an orchestrated character, that shock the conscience of humankind, that result in a significant number of victims, and that one would expect the international media and the international community to focus on as meriting an international response holding the lead perpetrators accountable before a competent court of law.

Here is the dilemma posed by the threshold of criminal conduct associated with atrocity crimes. This issue has been confronted with genocide, which in a technical sense can be found on the basis of the specific intent to kill one member of a designated group but which, in practice and in the enforcement of the law, requires a larger number of victims. Terms that describe the requirement well are "significant magnitude," "high threshold," "extreme gravity," and "significant numbers." The Rome Statute for the International Criminal Court refers to "unimaginable atrocities that deeply shock the conscience of humanity," "such grave crimes [as] threaten the peace, security and well-being of the world," and "the most serious crimes of concern to the international community as a whole."16

The resulting substantiality test provides a better understanding of atrocity crimes and the magnitude required to so classify them. There exists an ever-growing jurisprudence on the meaning of the terms "genocide," "crimes against humanity," and "war crimes," and one part of that exercise before the International Criminal Tribunals for the Former Yugoslavia (ICTY) and Rwanda (ICTR) has been to clarify the substantiality test that must be met.

With respect to genocide, the ICTR held in the Akayesu case that actual extermination of a group in its entirety is not required and that "a person could be found guilty of genocide without necessarily having to establish that genocide had taken place throughout the country concerned." ${ }^{17}$ But the ICTR Trial Chamber also held, in the Kayishema and Ruzindana judgment, that the reference to "in part" in the legal requirement of "intent to destroy in whole or in part," found in both the ICTR Statute and the UNCG, "requires the intention to destroy a considerable number of individuals who are part of the group."18 In the Bagilishema judgment, the Trial Chamber agreed

with the statement of the International Law Commission, that "the intention must be to destroy the group as such, meaning as a separate and distinct entity, and not merely some individuals because of their membership in [a] particular group." Although the destruction sought need not be directed at every member of the targeted group, the Chamber considers that the intention to destroy must target at least a substantial part of the group. ${ }^{19}$

The ICTY Trial Chamber held in the Krstic judgment that "an intent to destroy only part of the group must nevertheless concern a substantial part thereof, either numerically or qualitatively." 20 In Jelisic, the Trial Chamber held that "it is widely acknowledged that the intention to destroy must target at least a substantial part of the group." 21 
One of the US understandings to its ratification of the UNCG was to qualify "destruction of part of a group" as meaning a "substantial part" of that group. ${ }^{22}$ That understanding has now, for all intents and purposes, become established international law.

The ICTY, in its Jelisic decision, also elaborated two types of the substantiality test:

Genocidal intent may... be manifest in two forms. It may consist of desiring the extermination of a large number of the members of the group, in which case it would constitute an intention to destroy a group en masse. However, it may also consist of the desired destruction of a more limited number of persons selected [i.e., leadership of the group] for the impact that their disappearance would have upon the survival of the group as such. This would then constitute an intention to destroy the group "selectively." 23

In its Jelisic judgment, the ICTY Trial Chamber ruled that "genocide may be perpetrated in a limited geographic zone"; for example, it may be "limited to the size of a region or ... a municipality." 24 In Krstic, moreover, the court found that

the physical destruction may target only a part of the geographically limited part of the larger group because the perpetrators of the genocide regard the intended destruction as sufficient to annihilate the group as a distinct entity in the geographic area at issue. $^{25}$

In the Appeals Chamber judgment of Krstic, the substantiality requirement for genocide was a central finding regarding the Srebrenica massacre. The court found that the "part" must be a substantial part of the group; the part targeted must be significant enough to have an impact on the group as a whole. The court supported the Jelisic test of targeting at least a substantial part of the group, as well as the test, developed in the Sikirica judgment, that there must be evidence of an intention to destroy a substantial number relative to the total population of the group and an intention that there be an impact on the overall survival of the group. ${ }^{26}$

The Appeals Chamber also noted that the substantiality requirement is supported by scholarly opinion. It cited Lemkin's own view that the killing must be substantial, or on a mass scale. And it noted the International Law Commission's view that the crime of genocide requires the intent to destroy at least a substantial part of a particular group. The court then held that

The intent requirement under article 4 of the statute is therefore satisfied where evidence shows that the alleged perpetrator intended to destroy at least a substantial part of the protected group. The number of individuals targeted should be evaluated not only in absolute terms but also in relation to the overall size of the entire group. $^{27}$

The court subsequently focused on the issue of geographical area, finding that the importance of the 40,000 Muslims in Srebrenica is not captured solely by their numbers: "The capture and ethnic purification of Srebrenica would severely undermine the military efforts of the Bosnian Muslim state to ensure its viability. Elimination of the enclave would have accomplished the goal of purifying the entire region of its Muslim population."28 Therefore, Srebrenica was important "due to its prominence in the eyes of both the Bosnian Muslims and the international community (as a 'safe area')." 29 Thus the ambit of the genocidal enterprise in Krstic was limited to the area of Srebrenica. 
The Appeals Chamber also inferred from the actual killing of the protected group, men of military age, the intent to destroy a substantial part of the targeted group, the Bosnian Muslims of Srebrenica. The defense argued that ethnic cleansing is not genocide. The Trial Chamber had rejected the defense's argument that the killing of these men was motivated solely by the desire to eliminate them as a potential military threat; the extermination was not driven solely by a military rationale. The Appeals Chamber found that the Trial Chamber was entitled to consider the long-term impact that the elimination of 7,000 to 8,000 men from Srebrenica would have on the survival of that community. Such killings potentially consigned the community to extinction, and the court considered this the type of physical destruction that the UNCG is designed to prevent. Furthermore, the forcible transfer could be an additional means by which to ensure the physical destruction of the Bosnian Muslim community in Srebrenica, as it prevented the Muslim community from reconstituting itself. Killing women or children would have inflamed public opinion. $^{30}$

The Appeals Chamber found that while the intent to commit genocide must be supported by the factual matrix, the offense of genocide does not require proof that the perpetrator chose the most efficient method to accomplish his objective of destroying the targeted part. In this case, the perpetrators adopted the method that would allow them to implement the genocidal design while minimizing the risk of retribution. The fact that forcible transfer does not, in and of itself, constitute a genocidal act did not preclude the Trial Chamber from relying on it as evidence of the intentions of members of the Main Staff of the Army of the Republika Srpska (Serb Republic). The genocidal intent may be inferred, among other facts, from evidence of "other culpable acts systematically directed against the same group."31

The Appeals Chamber also found that where direct evidence of genocidal intent is absent, such intent may still be inferred from the factual circumstances of the crime. In the case of Srebrenica, the factual circumstances permit the inference that the killing of the Bosnian Muslim men was done with genocidal intent. The scale of the killing, combined with the VRS Main Staff's awareness of the detrimental consequences it would have on the Bosnian Muslim community of Srebrenica and with the other actions the Main Staff took to ensure that community's physical demise, is a sufficient factual basis for the finding of specific intent. ${ }^{32}$

The Appeals Chamber emphasized that the gravity of genocide is reflected in the stringent requirements that must be satisfied for a conviction: "The demanding proof of specific intent and the showing that the group was targeted for destruction in its entirety or in substantial part, guard against a danger that convictions for this crime will be imposed lightly." 33 The court continued,

By seeking to eliminate a part of the Bosnian Muslims, the Bosnian Serb forces committed genocide. They targeted for extinction the 40,000 Bosnian Muslims living in Srebrenica, a group which was emblematic of the Bosnian Muslims in general. They stripped all the male Muslim prisoners, military and civilian, elderly and young, of their personal belongings and identification, and deliberately and methodically killed them solely on the basis of their identity. The Bosnian Serb forces were aware, when they embarked on this genocidal venture, that the harm they caused would continue to plague the Bosnian Muslims. ${ }^{34}$

The Appeals Chamber stated "unequivocally that the law condemns, in appropriate terms, the deep and lasting injury inflicted, and calls the massacre at Srebrenica by its proper name: genocide." 35 
Although the Krstic Trial Chamber rejected only the cultural or social destruction of a group as constituting genocide, it pointed out

that where there is physical or biological destruction there are often simultaneous attacks on the cultural and religious property and symbols of the targeted group as well, attacks which may legitimately be considered as evidence of an intent to physically destroy the group. In this case, the Trial Chamber will thus take into account as evidence of intent to destroy the group the deliberate destruction of mosques and houses belonging to members of the group. ${ }^{36}$

The magnitude of such destruction can thus influence reaching a determination of genocide. The Krstic Appeals Chamber noted the Trial Chamber's observation and did not reject the conclusion that such destruction can be taken into account as evidence of intent to destroy the group. ${ }^{37}$

If one examines the substantiality requirement for crimes against humanity, one finds that the tribunals have established levels of gravity requisite to merit description as "atrocity crimes." Interestingly, article 5 of the ICTY Statute, which incorporates crimes against humanity into the subject-matter jurisdiction of the court, provides no literal substantiality requirement. But the ICTY jurisprudence does. First, the court has found that

It is sufficient to show that enough individuals were targeted in the course of the attack, or that they were targeted in such a way as to satisfy the Chamber that the attack was in fact directed against a civilian "population," rather than against a limited and randomly selected number of individuals. ${ }^{38}$

The ICTY also reads into article 5 the requirement that the attack be "either widespread or systematic in nature."39 In Kordic and Cerkez, the court found that "a crime may be widespread or committed on a large scale by the "cumulative effect of a series of inhumane acts or the singular effect of an inhumane act of extraordinary magnitude." 40 In Blaskic, the Trial Chamber ruled that "the widespread characteristic refers to the scale of the acts perpetrated and to the number of victims." ${ }^{11}$ Also in Blaskic, the court articulated the elements of a "systematic" attack:

The systematic character refers to four elements which... may be expressed as follows: (1) the existence of a political objective, a plan pursuant to which the attack is perpetrated or an ideology, in the broad sense of the word, that is, to destroy, persecute or weaken a community; (2) the perpetration of a criminal act on a very large scale against a group of civilians or the repeated and continuous commission of inhumane acts linked to one another; (3) the preparation and use of significant public or private resources, whether military or other; (4) the implication of high-level political and/or military authorities in the definition and establishment of the methodical plan. ${ }^{42}$

In Kunarac, Kovac, and Vokovic and in Jelisic, the ICTY emphasized that factors used to assess "widespread or systematic" include "the number of victims"43 and "the employment of considerable financial, military or other resources and the scale or the repeated, unchanging and continuous nature of the violence committed against a particular civilian population." 44

The crime of extermination, a long-standing crime against humanity, should be of most interest to scholars of genocide because it constitutes an alternative charge in an indictment that comes closest to the crime of genocide without having to prove the specific intent required for genocide. The Kristic Trial Chamber held that the definition "should be read as meaning the destruction of a 
numerically significant part of the population concerned." ${ }^{\prime 4}$ In Vasiljevic, the Trial Chamber found

that criminal responsibility for "extermination" only attaches to those individuals responsible for a large number of deaths, even if their part therein was remote or indirect. Responsibility for one or for a limited number of such killings is insufficient. ${ }^{46}$

The Krstic Trial Chamber offered a caveat, however: "While extermination generally involves a large number of victims, it may be constituted even where the number of victims is limited." ${ }^{47}$ The Vasilijevic Trial Chamber further required that "extermination must be collective in nature rather than directed towards singled out individuals." 48

Regarding the crime of persecution, which also can be a key element of genocidal intent, the ICTY, in Kordic and Cerkez, was careful to invoke the substantiality test, listing by example two acts that "do not constitute persecution as a crime against humanity because they do not rise to the same level of gravity as the other crimes against humanity enumerated in Article 5" of the ICTY Statute. Those two examples are "encouraging and promoting hatred on political grounds" and "dismissing and removing Bosnian Muslims from government."49

The residual clause listing "other inhumane acts" must satisfy the substantiality test as well. In Naletilic and Martinovic, the ICTY defined "other inhumane acts" as

acts that do not fall within any of the other sub-clause of Article 5 of the Statute but are sufficiently similar in gravity to the other enumerated crimes.... As constituting crimes against humanity, these acts must also be widespread or systematic. ${ }^{50}$

Article 3 of the ICTR Statute, which incorporates crimes against humanity in the subject-matter jurisdiction of the ICTR, explicitly invokes the language of "a widespread or systematic attack against any civilian population." In the Akayesu Trial Chamber decision, the court found that "the concept of 'widespread' may be defined as massive, frequent, large scale, carried out collectively with considerable seriousness and directed against a mutiplicity of victims." ${ }^{1}$ In Kayishema and Ruzindana, the ICTR Trial Chamber found that "a widespread attack is one that is directed against a multiplicity of victims." ${ }^{2}$ The attack on a civilian population

does not mean that the entire population of a given State or territory must be victimized by these acts in order for the acts to constitute a crime against humanity .... Instead the "population" element is intended to imply crimes of a collective nature and thus excludes single or isolated acts which, although possibly constituting crimes under national penal legislation, do not rise to the level of crimes against humanity. ${ }^{53}$

The specific crime of extermination requires that "the actor participates in the mass killing of others or in the creation of conditions of life that lead to the mass killing of others, through his act(s) or omission(s)."54

Finally, the substantiality test for war crimes is of a different character. Technically, there is no real substantiality test, other than that found in the 1949 Geneva Conventions for what constitutes a grave breach, and even then the issue pertains to the individual victim or victims rather than to any particularly substantial number of victims. Article 4 of the ICTR Statute incorporates into the subject-matter jurisdiction of the court the commission of "serious violations of Article 3 common to the Geneva Conventions..." This has been interpreted to mean "grave consequences for the victim." 55 The ICTY has mirrored this finding. In Kunarac, Kovac and Vokovic, a violation of the laws or customs of war "must be serious, that is to say, it must constitute a breach of a rule protecting important values, and the breach must involve 
grave consequences for the victim." ${ }^{56}$ Yet no indictment, and certainly no conviction, before either tribunal on war-crimes charges has sought to proceed with respect to isolated or singular violations of the Geneva Conventions or of the laws and customs of war. There is always a larger context to the war-crimes charges that involves a substantial degree of illegal conduct.

There are also important substantiality requirements built into the statutes of the permanent International Criminal Court, the Special Court for Sierra Leone, and the Extraordinary Chambers in the Courts of Cambodia. With respect to the Rome Statute of the International Criminal Court, US negotiators, myself included, sought to require that war crimes be committed "as part of a plan or policy and as part of a large-scale commission of such crimes." But we were rebuffed by other delegations and ultimately settled on "war crimes in particular when committed as part of a plan or policy or as part of a large-scale commission of such crimes." 57 This reflected the interests of governments to ensure that the 1949 Geneva Conventions would not become narrowly construed to apply only to planned or large-scale commissions of war crimes but could also be enforced against perpetrators of individual grave breaches. Yet the inference in all that was discussed and anticipated in the practice of the International Criminal Court was for a substantiality test to be met either through the execution of a policy or plan to commit war crimes (which infers a multiplicity of criminal acts) or through a large-scale commission of war crimes.

\section{Atrocity Law}

There has been a revolution in international humanitarian and criminal law since 1993. In conventional legal terminology, however, no term describes precisely what the international and hybrid criminal tribunals have the jurisdiction to prosecute. The crimes in question are not only genocide, or crimes against humanity, or war crimes; they need a unifying term. The law applied by the criminal tribunals is not only international humanitarian law, not only international criminal law, not only international human-rights law, not only military law, and not only serious crimes under international law.

The law of the criminal tribunals is uniquely crafted, the enforcement mechanism is uniquely conceived, and the political mandate of each of these courts is uniquely tailored. They need a truly relevant term to describe the reality of their jurisdiction and their role in framing legal responses to war crimes, genocide, crimes against humanity, and other heinous crimes.

The international community has faced this situation before. The crime of genocide identified by Raphael Lemkin arose from his concern that the Holocaust could not be properly defined or prosecuted as simply a crime against humanity. The constituent parts of the crime were unique, and conventional international law did not address those unique characteristics of intent, target, and context. With Lemkin's perseverance, the UNCG defined the new crime of genocide.

Similarly, today we are confronted with an inadequate lexicon for the crimes and law that underpin the criminal tribunals. In a fundamental way, the relatively rapid establishment of these criminal tribunals has outstripped the capacity of the law to remold itself into an easily identifiable legal weapon for them to wield. It is no idle matter, this quest for terminology. Getting the terminology right is part of the accuracy and integrity of the process, and it is part of the job of selling to the public the credibility and utility of these judicial institutions. If public support for international prosecution and military responses to atrocity crimes is lost because 
what is described appears threatening or incomprehensible to the average person, then the entire venture will be undermined.

Atrocity law is the law applied to atrocity crimes; it is drawn from several disciplines of international law: international criminal law, international humanitarian law, international human-rights law, and the law of war; and it is applied primarily by international and hybrid criminal tribunals.

An unfortunate inaccuracy appears repeatedly in UN Security Council and General Assembly resolutions, in legislation by the US Congress and European parliaments, and in the public pronouncements of governments and non-governmental organizations. The body of law purportedly covering atrocity crimes is typically referred to as "international humanitarian law" and the crimes described as "violations of international humanitarian law." Such is not necessarily the case, however. More often, the relevant criminal conduct engages several fields of established law-international humanitarian law, international criminal law, international human-rights law, the laws and customs of war, and military law. For any particular situation of atrocities and the subject-matter jurisdiction of any particular criminal tribunal, however, there is one field of law-atrocity law-that overlaps parts of each of these separate fields of law but never encompasses any one of them entirely.

Briefly, international humanitarian law establishes norms to protect certain categories of persons and property and prohibits attacks against them during the course of an armed conflict of an international or non-international character. But it can exclude some parts of the laws of war whose primary purpose is not humanitarian, and it does not concern either genocide or crimes against humanity that occur outside the ambit of armed conflict. Most of international humanitarian law cannot be prosecuted against an individual and concerns state practice and state responsibility in armed conflicts.

The conventions of international criminal law range far beyond atrocities. Less than half of the at least twenty-four categories of international criminal law pertain to atrocities. International criminal law does not incorporate most of international humanitarian law or international human rights law. While international criminal law will always apply to atrocity crimes and atrocity law, it would be deeply misleading to use the term to describe the kind of actions and the kind of law that are of direct concern to international criminal tribunals. The term fails the tests of magnitude, of targeting the leading perpetrators, and of isolating only those crimes accurately described as "atrocities."

International human-rights law is inappropriate to criminal tribunals, as it has traditionally, in its relatively short history, concerned the political responsibility of states for violations against individual victims, not the criminal responsibility of individual perpetrators. Until relatively recently, human-rights law did not seek to govern the conduct of states during warfare, which is the circumstance that so often accompanies atrocities. There is now considerable tension between human-rights law and the law of war as the former seeks to intrude more aggressively into the domain of warfare. Much of human-rights law requires the breathing space afforded by the absence of penal provisions. Atrocity law, as I would define it, requires criminal sanction, and it concerns only those human-rights violations that can be prosecuted as crimes and are committed on a scale and in circumstances that only scratch the surface of the full range of human-rights violations and law. 
Military or court-martial law and, in most respects, the law of war pertain solely to war crimes and, through generically relevant crimes such as murder, to crimes against humanity and genocide. But it is an entirely unsatisfactory body of law to cover the criminality of individual perpetrators of atrocity crimes, particularly non-military perpetrators.

The following characteristics of atrocity law draw from the international and hybrid criminal tribunals:

- No two criminal tribunals share exactly the same law. The law is selected and edited to conform to the circumstances of the crimes and to the context within which they were committed. In the Special Court for Sierra Leone, the Extraordinary Chambers in the Courts of Cambodia, the special courts in Kosovo and East Timor, and the Iraqi High Criminal Court, domestic law also figures prominently. In fact, the principle of complementarity in the Rome Statute of the ICC invites a significant and potentially exclusive role for national criminal law in achieving the objectives of the permanent court.

- Personal jurisdiction is limited either implicitly, by virtue of the substantiality test required of the crime and, one might argue, the practical limitations of the tribunal (e.g., the ICC, ICTY, and ICTR), or explicitly by the terms of the statute itself (e.g., the Special Court for Sierra Leone and the Extraordinary Chambers in the Courts of Cambodia).

- Some categories of atrocity law have evolved and acquired greater precision with more recently established tribunals.

- One can look beyond the statutes of the tribunals to case law, as for the substantiality test, for a further understanding of atrocity crimes and atrocity law.

If "atrocity crimes" and "atrocity law" were to become part of the lexicon for the crimes and law of the international and hybrid criminal tribunals, these terms would help with several issues:

- The criminal tribunals are having the perhaps unintended effect of encouraging a shift away from state responsibility toward individual criminal responsibility, and a shift from low-magnitude crimes to high-magnitude crimes as the focus of judicial enforcement. It is easier to charge a state with the commission of atrocity crimes than it is to charge a particular type of atrocity crime. While the criminal tribunals rightly act with great precision to prosecute the crime of genocide, crimes against humanity, and serious war crimes, there remains a need to elevate once again the responsibility of governments not to commit these crimes. An effective way of doing this would be to use the language of atrocity crimes to describe what a state appears responsible for committing, whether or not a specific atrocity crime can be identified quickly.

- Use of the terms "atrocity crimes" and "atrocity law" would enhance the unique character and accuracy of the conventional terminology, which otherwise risks becoming blurred with overlapping applications and incomplete descriptions of what the criminal tribunals actually enforce. In other words, one would not have to misconstrue the terms "international humanitarian law," "criminal law," or "the law of war" to describe the applicable law of the criminal tribunals. Likewise, one would not need to misconstrue "genocide," "crimes against humanity," or "war crimes" to describe the killings, violence, and destruction actually taking place. 
- The presumption of the criminal tribunals is that the leading perpetrators of the atrocity crimes will be prosecuted before the criminal tribunal, whereas the mid- and lower-level perpetrators will either be prosecuted before competent domestic courts or handled through a non-judicial mechanism, such as a truth and reconciliation commission, determined at the national or local level. By focusing on atrocity crimes and atrocity law in describing the jurisdiction of the criminal tribunals, one can more clearly delineate between the international and domestic mechanisms of justice that are evolving. Theoretically, of course, a criminal tribunal should have the legal tools to prosecute the foot soldier for a grave breach of the 1949 Geneva Conventions, or a local policeman for participating in mass rape during a genocidal rampage. But the international community and national governments are drawing a different line, using scarce resources for criminal tribunals that prosecute crimes meeting the criteria that have been set forth and encouraging alternative mechanisms at the national level for the typically much larger number of mid- and low-level perpetrators. Atrocity crimes and atrocity law better distinguish between those two levels of justice and rehabilitation.

- Humanitarian intervention and the more recent articulation of a responsibility to protect civilian populations at risk, ${ }^{58}$ both of which remain controversial areas of international law, might be better understood and more supportable politically if the objective of the intervention or action to protect were to end or prevent an atrocity crime, rather than having politicians, military commanders, and their government lawyers and spokespersons claim that such massive military measures are required to confront war crimes, crimes against humanity, or violations of international humanitarian law. The crime of genocide can be left untethered as a powerful public rationale for humanitarian intervention or an action to protect. But short of literally calling the situation a genocide, which experience demonstrates is a struggle for governments and international organizations, there is need for a powerful and accurate term that can be readily understood as justifying the extraordinary and legally controversial initiative of a humanitarian intervention or action to protect civilian populations at risk. That term is "atrocity crimes." The technical use of "genocide," "crimes against humanity," or "war crimes" may be accurate in a particular situation, but humanitarian interventions and actions under the principle of responsibility to protect require the building of popular support, as well as international support, to sustain them in times of great crisis and to preserve for the states involved the right and ability to intervene for humanitarian purposes again. The public might better appreciate the need for military intervention if the term "atrocity crimes" was used in association with responses to clearly horrific and unacceptable assaults on civilian populations, rather than legal terminology (particularly "crimes against humanity," "ethnic cleansing," "war crimes," and even "genocide") that can be understood by lawyers as extremely meaningful (and horrific) but to the public remains foggy at best. The legality of any particular humanitarian intervention or action to protect is a separate debate. But there is great utility for a more focused and easily understood jurisdictional description- "atrocity crimes"-for governments, international organizations, and criminal tribunals in relation to atrocity prevention and termination. 
The next step might be to incorporate such terms in UN Security Council resolutions and UN reports and in legislative resolutions, as well as pleadings, decisions, and judgments of the international and hybrid criminal tribunals. There would be considerable utility in forging a UN General Assembly resolution that would recommit the international community to react swiftly to the commission of atrocity crimes, which could be expressly stated as such in the resolution and then described as including genocide, crimes against humanity, and serious war crimes. But it may take a number of years of use of the term "atrocity crimes," particularly by political leaders and leading scholars, and the continued unleashing of atrocities without effective response, for such codification of the term to occur. ${ }^{59}$

\section{Conclusion}

The prospect of the term "genocide" arising in policy making too often puts an intimidating brake on effective responses. I have argued here that the political use of the term should be separated from its legal definition as a crime of individual responsibility. Governments and international organizations should be liberated to apply the term "genocide" more readily, within a political context, to publicly describe precursors of genocide and react rapidly either to prevent or to stop mass killings or other acts of genocide. Precursors of genocide are those events occurring immediately prior to and during a possible genocide that can point to an ultimate legal judgment of genocide but which should be recognized and used in a timely manner to galvanize international action to intervene, whether diplomatically, economically, or militarily. Policy makers should not be constrained from acting by the necessity of a prior legal finding that the crime of genocide in fact has occurred or is occurring and, once that legal finding has been made, that any such finding would automatically obligate governments to use military force in response.

There also is a critical need for a new term- "atrocity crimes"-and a new field of international law-atrocity law-to achieve a similar objective, namely, to enable public and academic discourse to describe genocide, crimes against humanity (including ethnic cleansing), and war crimes with a single term that is easily understood by the public and accurately reflects the magnitude and character of the crimes adjudicated before international and hybrid criminal tribunals and of the law being applied in practice by such tribunals and by governments and international organizations. The purpose would be to simplify and yet render more accurate both public dialogue and legal terminology describing genocide and other atrocity crimes.

\section{Notes}

1. See Samantha Power, "A Problem from Hell": America and the Age of Genocide (New York: Basic Books, 2002), 17-78.

2. US Department of State, Documenting Atrocities in Darfur (Washington, DC: Bureau of Democracy, Human Rights and Labor and Bureau of Intelligence and Research, 2004), http://www.state.gov/g/drl/rls/36028.htm (accessed 13 October 2006).

3. See Convention on the Prevention and Punishment of the Crime of Genocide, 9 December 1948, 102 Stat. 3045, 78 U.N.T.S. 277, http://www.unhchr.ch/html/menu3/b/p_genoci.htm (accessed 5 October 2006). Article I reads in full: "The Contracting Parties confirm that genocide, whether committed in time of peace or in time of war, is a crime under international law which they undertake to prevent and to punish."

4. David Scheffer, Ambassador-at-Large for War Crimes Issues, On-the-Record Briefing on Atrocities in Kosovo released by the Office of the Spokesman, US Department of State, 
Washington, DC, 9 April 1999, http://www.state.gov/www/policy_remarks/1999/ 990409_scheffer_kosovo.html (accessed 5 October 2006).

5. The information conveyed in the next four paragraphs was reported in my 9 April 1999 press briefing, ibid.

6. Ibid.

7. See Power, A Problem from Hell, 329-89; David Scheffer, "Lessons from the Rwandan Genocide," Georgetown Journal of International Affairs 5 (2004): 125-32.

8. See Report of the International Commission of Inquiry on Darfur to the United Nations Secretary-General, Pursuant to Security Council Resolution 1546 of 18 September 2004 (25 January 2005), para. 184, http://www.un.org/News/dh/sudan/com_inq_darfur.pdf (accessed 5 October 2006) [COI Report].

9. Ibid., paras. $489-522$.

10. Ibid., paras. $640-41$.

11. See Emily Wax, "U.N. Report on Sudan Draws Mixed Reaction," Washington Post, 2 February 2005, A16; see also David Scheffer, "How to Bring Atrocity Criminals to Justice," Financial Times (London), 2 February 2005, 13.

12. See COI Report, paras. 182-418, 630-39, 642 .

13. Quotations from The Fugitive, directed by Andrew Davis (Warner Bros., 1993), http://www.imdb.com/title/tt0106977/quotes (accessed 5 October 2006).

14. Certain passages that follow are drawn from an earlier law review article: David Scheffer, "The Future of Atrocity Law," Suffolk Transnational Law Review 25 (2002): 389-432.

15. Mark J. Osiel, Obeying Orders (New Brunswick, NJ: Transaction Publishers, 1999), 45.

16. Rome Statute of the International Criminal Court, U.N. Doc. A/CONF.183/9 (17 July 1998), Preamble, reprinted in 37 I.L.M. 999 (1998).

17. Prosecutor v. Akayesu, Judgment, ICTR-96-4-T (2 September 1998), n. 61 [Akayesu Trial Judgment].

18. Prosecutor v. Kayishema and Ruzindana, Judgment, ICTR-95-1-T (21 May 1999), paras. 96-97 [Kayishema Trial Judgment].

19. Prosecutor v. Bagilishema, Judgment, ICTR-95-1A-T (7 June 2001), para. 64 [Bagilishema Trial Judgment].

20. Prosecutor v. Krstic, Judgment, IT-98-33-T (2 August 2001), para. 634 [Krstic Trial Judgment].

21. Prosecutor v. Jelisic, Judgment, IT-95-10-T (14 December 1999), para. 82 [Jelisic Trial Judgment].

22. US Reservations and Understandings to the Genocide Convention, 28 I.L.M. 782 (1989). The first US understanding reads, "That the term 'intent to destroy, in whole or in part, a national, ethnical, racial, or religious group as such' appearing in article II means the specific intent to destroy, in whole or in substantial part, a national, ethnical, racial or religious group as such by the acts specified in article II."

23. Jelisic Trial Judgment, para. 82.

24. Ibid., para. 83.

25. Krstic Trial Judgment, para. 590 .

26. Prosecutor v. Krstic, Judgment, IT-98-33-A (19 April 2004), paras. 6-8 [Krstic Appeals Judgment].

27. Ibid., paras. 9-12.

28. Ibid., paras. 13-15.

29. Ibid., para. 16 .

30. Ibid., paras. 24-31.

31. Ibid., paras. 32-33.

32. Ibid., paras. 34-35.

33. Ibid., para. 37.

34. Ibid., para. 37.

35. Ibid., para. 37.

36. Ibid., para. 580 . 
37. Ibid., para. 25.

38. Prosecutor v. Kunarac, Kovac and Vokovic, Judgment, IT-96-23 \& IT-96-23/1-A (12 June 2002), para. 90 [Kunarac Appeals Judgment].

39. Prosecutor v. Naletilic and Martinovic, Judgment, IT-98-34-T (31 March 2003), para. 236 [Naletilic Trial Judgment].

40. Prosecutor v. Kordic and Cerkez, Judgment, IT-95-14/2-T (26 February 2001), para. 179 [Kordic Trial Judgment].

41. Prosecutor v. Blaskic, Judgment IT-95-14-T (3 March 2000), para. 206.

42. Ibid., para. 203.

43. Kunarac Appeals Judgment, para. 95.

44. Jelisic Trial Judgment, para. 53 .

45. Krstic Trial Judgment, para. 502.

46. Prosecutor v. Vasiljevic, Judgment, IT-98-32-T (29 November 2002), para. 227 [Vasiljevic Trial Judgment].

47. Krstic Trial Judgment, para. 501.

48. Vasiljevic Trial Judgment, para. 227.

49. Kordic Trial Judgment, paras. 208-10.

50. Naletilic Trial Judgment, para. 247.

51. Akayesu Trial Judgment, para. 580.

52. Kayishema Trial Judgment, para. 123.

53. Bagilishema Trial Judgment, para. 80.

54. Kayishema Trial Judgment, para. 144.

55. Akayesu Trial Judgment, para. 616; Prosecutor v. Rutaganda, ICTR-96-3-T (6 December 1999), para. 106.

56. Kunarac Appeals Judgment, para. 66.

57. Rome Statute, art. 8 (emphasis added).

58. See World Summit Outcome, UN Document A/RES/60/1, paras. 138, 139 (2005).

59. An example of the use of the term "atrocity crimes" can be found in International Crisis Group, Darfur: The Failure to Protect, Africa Report No. 89 (8 March 2005), http://www.crisisgroup.org/home/index.cfm?id=3314\&l=1 (accessed 5 October 2006). 